\title{
$\beta$-Carboline Alkaloids from Galianthe ramosa Inhibit Malate Synthase from Paracoccidioides spp.
}

Authors

Affiliations
Carla S. de Freitas ${ }^{1}$, Lucilia Kato ${ }^{1}$, Cecília M. A. de Oliveira ${ }^{1}$, Luiz H. K. Queiroz jr. ${ }^{1}$, Mábio J. Santana ${ }^{1}$, Ivânia T. Schuquel ${ }^{2}$, Piero G. Delprete ${ }^{3}$, Roosevelt A. da Silva ${ }^{4}$, Guilherme O. Quintino ${ }^{4}$, Benedito R. da Silva Neto ${ }^{5}$, Célia M. A. Soares ${ }^{5}$, Maristela Pereira ${ }^{5}$

The affiliations are listed at the end of the article

\author{
Key words \\ - Galianthe ramosa \\ - Rubiaceae \\ indole alkaloids \\ - malate synthase \\ - Paracoccidioides spp.
}

\begin{abstract}
$\nabla$

As part of our continuing chemical and biological analyses of Rubiaceae species from Cerrado, we isolated novel alkaloids $\mathbf{1}$ and $\mathbf{2}$, along with known compounds epicatechin, ursolic acid, and oleanolic acid, from Galianthe ramosa. Alkaloid 2 inhibited malate synthase from the pathogenic fungus Paracoccidioides spp. This enzyme is considered an important molecular target because it is not found in humans. Molecular docking simulations were used to describe the interactions between the alkaloids and malate synthase.
\end{abstract}

$\begin{array}{ll}\text { Abbreviations } \\ \nabla \\ \text { AL: } & \text { ethyl acetate } \\ \text { ASA: } & \text { accessible surface area } \\ \text { CL: } & \text { chloroform } \\ \text { DTNB: } & 5,5^{\prime} \text {-dithiobis-(2-nitrobenzoic acid) } \\ \text { EEF: } & \text { ethanolic extract of the flowers }\end{array}$

\section{Introduction}

$\begin{array}{ll}\text { received } & \text { Sept. 6, 2013 } \\ \text { revised } & \text { October 1, } 2014\end{array}$

accepted October 12, 2014

\section{Bibliography}

DOI http://dx.doi.org/

10.1055/s-0034-1383305

Published online November 20, 2014

Planta Med 2014; 80:

1746-1752 @ Georg Thieme

Verlag KG Stuttgart · New York .

ISSN 0032-0943

\section{Correspondence}

\section{Prof. Dr. Lucilia Kato}

Instituto de Química

Universidade Federal de Goiás,

Campus Samambaia

74001-970 - Goiânia, GO

Brazil

Phone: + 556235211008

Fax: + 556235211167

lucilia@ufg.br

\section{$\nabla$}

Paracoccidioides spp. are dimorphic fungi that cause PCM, the most prevalent invasive fungal disease in South America [1]. Distinct forms of PCM exist [2], and prolonged treatment regimens are required to treat patients with the more severe forms, resulting in greater toxicity and disease relapse [3]. In addition, cases of PCM associated with AIDS have recently been reported [4-5]. Over the last decade, efforts have been focused on finding specific targets for antifungal drugs that are absent in mammalian cells. The role of the glyoxylate cycle and the associated enzymes ICL and MLS in microbial virulence has been reported for several pathogens, including Mycobacterium tuberculosis [6], Candida albicans [7-8], Cryptococcus neoformans [9], Paracoccidioides spp., and
EEL: ethanolic extract of the leaves

EER: ethanolic extract of the roots

EES: ethanolic extract of the stems

Fs: femtoseconds

HL: $\quad$ hexane

ICL: isocitrate lyase

MD: molecular dynamics

MIC: minimal inhibitory concentration

ML: methanol

MLS: malate synthase

ns: nanoseconds

PbICL: $\quad$ isocitrate lyase from Paracoccidioides spp.

PbMLS: malate synthase from Paracoccidioides spp.

PCM: paracoccidioidomycosis

PDB: $\quad$ Brookhaven Protein Data Bank

RMSD: root-mean-square deviation

Supporting information available online

http://www.thieme-connect.de/products

the phytopathogenic fungus Magnaporthe grisea [10]. The expression of the MLS gene in Paracoccidioides spp. is induced during the infection process, suggesting that this enzyme plays an important role in the establishment of infection [1114]. Therefore, this enzyme may be an attractive target for novel antifungal agents against PCM. Indole alkaloids are a diverse and complex class of natural products. Because this class has been found to exhibit a wide range of biological activities, including antifungal activity, we included carboline alkaloids isolated from Rubiaceae species in our antifungal screening program to identify natural molecules with the potential to inhibit Paracoccidioides spp. growth and PbMLS activity.

In this paper, we describe the structural elucidation of two novel indole alkaloids, 1 and 2, iso- 


\begin{tabular}{|c|c|c|c|c|}
\hline \multirow[t]{2}{*}{$\#$} & \multicolumn{2}{|c|}{${ }^{13} \mathrm{C} / \mathrm{HSQC}^{*}$} & \multicolumn{2}{|l|}{$\delta^{1} \mathrm{H}(\mathrm{H}$ mult: $J$ in $\mathrm{Hz}$ ) } \\
\hline & 1 & 2 & 1 & 2 \\
\hline 1 & - & - & $9.57(1 \mathrm{H} ; \mathrm{br} \mathrm{s})$ & $9.39(1 \mathrm{H} ; \mathrm{s})$ \\
\hline 2 & 135.4 & 135.3 & - & - \\
\hline 3 & 141.9 & 142.7 & - & - \\
\hline 4 & & - & - & - \\
\hline 5 & 138.3 & 138.5 & $8.33(1 \mathrm{H} ; \mathrm{d} ; 5.4)$ & $8.40(1 \mathrm{H} ; \mathrm{d} ; 5.3)$ \\
\hline 6 & 114.5 & 115.4 & $7.89(1 \mathrm{H} ; \mathrm{d} ; 5.4)$ & $8.02(1 \mathrm{H} ; \mathrm{d} ; 5.3)$ \\
\hline 7 & 128.3 & 127.8 & - & - \\
\hline 8 & 106.3 & 112.1 & - & - \\
\hline 9 & 157.5 & 157.2 & - & - \\
\hline 10 & 91.9 & 100.4 & $6.28(1 \mathrm{H} ; \mathrm{d} ; 1.8)$ & $6.68(1 \mathrm{H} ; \mathrm{d} ; 8.1)$ \\
\hline 11 & 162.3 & 129.3 & - & $7.45(1 \mathrm{H} ; \mathrm{t} ; 8.1)$ \\
\hline 12 & 87.2 & 104.4 & $6.54(1 \mathrm{H} ; \mathrm{d} ; 1.8)$ & $7.11(1 \mathrm{H} ; \mathrm{d} ; 8.1)$ \\
\hline 13 & 142.8 & 141.8 & - & - \\
\hline 14 & 57.6 & 57.5 & $3.76(1 \mathrm{H} ; \mathrm{d} ; 11.0)$ & $3.78(1 \mathrm{H} ; \mathrm{d} ; 11.8)$ \\
\hline 15 & 83.3 & 83.4 & - & - \\
\hline 16 & 41.8 & 41.9 & $\begin{array}{l}2.01-1.94(1 \mathrm{H} ; \mathrm{m}) 2.13-2.04 \\
(1 \mathrm{H} ; \mathrm{m})\end{array}$ & $\begin{array}{l}2.01-1.94(1 \mathrm{H} ; \mathrm{m}) \\
2.13-2.04(1 \mathrm{H} ; \mathrm{m})\end{array}$ \\
\hline 17 & 28.6 & 28.6 & $\begin{array}{l}1.90-1.83(1 \mathrm{H} ; \mathrm{m}) \\
2.13-2.04(1 \mathrm{H} ; \mathrm{m})\end{array}$ & $\begin{array}{l}1.95-1.87(1 \mathrm{H} ; \mathrm{m}) \\
2.13-2.04(1 \mathrm{H} ; \mathrm{m})\end{array}$ \\
\hline 18 & 46.5 & 46.5 & $3.72-3.67(1 \mathrm{H} ; \mathrm{m})$ & $3.75-3.71(1 \mathrm{H} ; \mathrm{m})$ \\
\hline 19 & 147.3 & 147.3 & - & - \\
\hline 20 & 109.5 & 109.8 & $4.61(1 \mathrm{H} ;$ br s) & $4.68(1 \mathrm{H} ; \mathrm{br} \mathrm{s})$ \\
\hline & & & $4.67(1 \mathrm{H} ; \mathrm{br} \mathrm{s})$ & $4.63(1 \mathrm{H} ; \mathrm{br} \mathrm{s})$ \\
\hline 21 & 20.9 & 21.5 & $1.71(3 \mathrm{H} ; \mathrm{s})$ & $1.74(3 \mathrm{H} ; \mathrm{s})$ \\
\hline 22 & 25.5 & 25.9 & $0.98(3 \mathrm{H} ; \mathrm{s})$ & $0.98(3 \mathrm{H} ; \mathrm{s})$ \\
\hline $9-\mathrm{OCH}_{3}$ & 55.6 & 55.7 & $4.01(3 \mathrm{H} ; \mathrm{s})$ & $4.07(3 \mathrm{H} ; \mathrm{s})$ \\
\hline $11-\mathrm{OCH}_{3}$ & 55.8 & & $3.86(3 \mathrm{H} ; \mathrm{s})$ & - \\
\hline
\end{tabular}

Table $1{ }^{1} \mathrm{H}$ and ${ }^{13} \mathrm{C} / \mathrm{HSQC}$

$\left(500.15 \mathrm{MHz}, \mathrm{CDCl}_{3}\right)$ NMR data for alkaloids $\mathbf{1}$ and $\mathbf{2}$.

${ }^{*}{ }^{13} \mathrm{C}$ chemical shifts were measured from indirect dimension of HSQC and HMBC experiments

lated from the aerial part of Galianthe ramosa E. L. Cabral (Rubiaceae). We also describe their activity against Paracoccidioides spp. and PbMLS as well as the results of molecular docking investigations.

\section{Results and Discussion \\ $\nabla$}

Alkaloid 1 was obtained as a brown solid and was found to contain a nitrogen functionality based on TLC analysis with Dragendorff's reagent. Analysis of the HRMS data indicated that compound 1 possesses the molecular formula $\mathrm{C}_{22} \mathrm{H}_{26} \mathrm{~N}_{2} \mathrm{O}_{3}\left[(\mathrm{M}+\mathrm{H})^{+}\right.$: $m / z$ 367.2027, calcd. $m / z$ 367.2022]. The IR spectrum suggested the presence of an $\mathrm{NH}$ and/or $\mathrm{OH}\left(3390 \mathrm{~cm}^{-1}\right)$ functionality and an alkene group $\left(1625 \mathrm{~cm}^{-1}\right)$. The ${ }^{1} \mathrm{H}$ NMR spectrum showed resonances at $\delta 8.33(1 \mathrm{H}, \mathrm{d}, J=5.4 \mathrm{~Hz}), 7.89(1 \mathrm{H}, \mathrm{d}, J=5.4 \mathrm{~Hz}), 6.28$ $(1 \mathrm{H}, \mathrm{d}, J=1.8 \mathrm{~Hz})$, and $6.54(1 \mathrm{H}, \mathrm{d}, J=1.8 \mathrm{~Hz})$ that were correlated with $\delta_{\mathrm{c}}$ at $138.3,114.5,91.9$, and 87.2, respectively (Table 1 ), which suggested the presence of a tetrasubstituted phenyl ring and a 1,2-pyridine ring. The presence of seven quaternary $\mathrm{sp}^{2}$ carbons at 135.4 (C-2), 141.9 (C-3), 128.7 (C-7), 106.3 (C-8), 157.5 (C-9), 162.3 (C-11), and 142.8 (C-13), the HMBC correlations between $\mathrm{H}-6$ and $\mathrm{C}-8$ (106.3) and C-2 (135.4), as well as the $\mathrm{H}-5 / \mathrm{C}-7$ (128.3), H-10/C8 (106.3) and H-12/C-10 (91.9) correlations indicated the presence of a disubstituted moiety, $\beta$-carboline. In the HSQC spectrum, the resonances at $\delta 4.01(3 \mathrm{H}, \mathrm{s})$ and $3.86(3 \mathrm{H}, \mathrm{s})$ were correlated with the resonances at 55.6 and 55.8 , respectively, and $\mathrm{HMBC}$ correlations existed between both $\mathrm{C}-9$ $\left(\delta_{\mathrm{c}} 157.5\right)$ and $\mathrm{C}-11\left(\delta_{\mathrm{c}} 162.3\right)$ and these methoxy groups. These correlations corroborated the presence of a meta-substituted $\beta$ carboline core at C-9 and C- 11 . Four methylene hydrogens, $\delta$
2.13-1.94 (m, H-16 and H-17), were correlated with $\delta 41.8$ and 28.6, and two methine hydrogens, $\delta 3.72-3.67(1 \mathrm{H}, \mathrm{m}, \mathrm{H}-18)$ and $\delta 3.76(1 \mathrm{H}, \mathrm{d}, J=11 \mathrm{~Hz})$, were correlated with $\delta_{\mathrm{c}} 46.5$ and 57.6 , respectively. An oxymethine carbon was also observed at $\delta$ 83.3. The COSY correlations $\mathrm{H}-16 / \mathrm{H}-17 / \mathrm{H}-18$ and the HMBC correlations $\mathrm{H}-14 / \mathrm{C}-15 / \mathrm{C}-16$ confirmed the presence of a cyclopentane unit in alkaloid 1. Additionally, in the HMBC spectrum, the methyl group at $\delta 0.98(3 \mathrm{H}, \mathrm{s}, \mathrm{H}-22)$ was correlated with $\mathrm{C}-15(\delta$ 83.3), suggesting that this five-membered ring was substituted with hydroxy and methyl groups.

The indole unit and the cyclopentane ring were found to be connected at C-3 and C-14, as demonstrated by the HMBC correlation between the hydrogen at $\delta 3.76(1 \mathrm{H}, \mathrm{d}, \mathrm{H}-14)$ and 141.9 (C3). Additionally, a $\mathrm{CH}_{3} \mathrm{CCH}_{2}$ fragment was suggested by the presence of the signal of methylene group at $\delta 4.61(1 \mathrm{H}, \mathrm{br} \mathrm{s}, \mathrm{H}-20 \mathrm{a})$ and $\delta 4.67\left(1 \mathrm{H}\right.$, br s, H-20b) and the $\mathrm{sp}^{2}$ carbon at 109.5. Furthermore, the methyl hydrogens at $\delta 1.71(3 \mathrm{H}, \mathrm{s}, \mathrm{H}-21)$ were correlated with $\delta_{\mathrm{c}} 20.9(\mathrm{C}-21)$ in the HSQC spectrum and with C-20 (109.5) and 147.4 (C-19) in the HMBC spectrum, which corroborated the presence of an isopropenyl unit.

The main HMBC correlations, H-14/C-3/C-15/C-18 and H-20/C18, demonstrated that the three units are connected (Fig. 17S, Supporting Information). Further HMBC correlations are listed in Table 1S, Supporting Information. All of these data were consistent with the proposed structure for novel alkaloid 1. Our data for alkaloid 1 were compared with available literature data for the alkaloid 1-(hydroxymethyl)-3-(2-hydroxypropan-2-yl)-2-(5methoxy-9H- $\beta$-carbolin-1-yl) cyclopentanol isolated from $\mathrm{Ga}$ lianthe thalictroides [15], and this comparison showed that these two alkaloids possess a similar substructure. 
The relative configuration of the stereocenter at C-14 was determined based on the coupling constant of $\mathrm{H}-14$ ( $\delta 3.76, \mathrm{~d}, J=11.0)$,

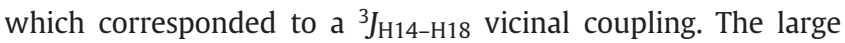
coupling constant observed from the cis orientation pattern was confirmed by theoretical calculations of the spin-spin coupling constants. The calculated ${ }^{3} J_{\mathrm{H} 14-\mathrm{H} 18}$ vicinal coupling constants were $8.5 \mathrm{~Hz}$ and $10.5 \mathrm{~Hz}$ for the trans isomer and cis isomer, respectively. These results clearly agree with the experimental ${ }^{3} J_{\mathrm{H} 14-\mathrm{H} 18}$ and indicate a cis substitution pattern for the five-membered ring. In addition, the NOE difference peaks for H-14/H-16/ $\mathrm{H}-17$ and $\mathrm{H}-18$ that were observed when the methyl group was irradiated verified that $\mathrm{H}-14$ and $\mathrm{H}-18$ were in the cis orientation. Alkaloid 2 showed spectroscopic data similar to those of alkaloid 1.

The analysis of the HRMS data indicated that compound 2 possesses the molecular formula $\mathrm{C}_{21} \mathrm{H}_{24} \mathrm{~N}_{2} \mathrm{O}_{2}\left[(\mathrm{M}+\mathrm{H})^{+}: \mathrm{m} / \mathrm{z}\right.$ 337.1965, calcd. $m / z$ 337.1916]. This ion was 30 amu lighter than that for alkaloid $\mathbf{1}$, suggesting that compound $\mathbf{2}$ contains only one methoxy unit.

The ${ }^{1} \mathrm{H}$ NMR, HSQC and HMBC correlations are listed in Tables 15 and 2 S, Supporting Information. Only one methoxy group, at $\delta$ $4.07(\mathrm{~s}, 3 \mathrm{H})$, was present, and it was correlated with $\delta \mathrm{c} 55.7$. The HMBC correlation of this methoxy group with the resonance at 157.2 and the ${ }^{13} \mathrm{C}$ assignments for the aromatic ring system suggested that this group was on the 9-position of the $\beta$-carboline indole ring. The comparison of the data for alkaloids $\mathbf{2}$ and $\mathbf{1}$ indicated that alkaloid $\mathbf{2}$ is a 9-methoxyindole alkaloid derivative. Epicatechin, ursolic acid and a mixture containing ursolic acid and oleanolic acid were also isolated from G. ramosa, and the spectroscopic data for these compounds agreed with those from the literature [16-17].

Alkaloids 1 and $\mathbf{2}$ ( Fig. $\mathbf{1}$ ) were tested for activity against Paracoccidioides spp. and its enzyme PbMLS. Both $\mathbf{1}$ and $\mathbf{2}$ inhibited the growth of Paracoccidioides spp., with MIC values of $185 \mu \mathrm{M}$ and $26 \mu \mathrm{M}$, respectively. For the antifungal amphotericin B (Sigma-Aldrich; from Streptomyces sp., approx. $80 \%$ by HPLC), the MIC value was $0.270 \mu \mathrm{M}$. We evaluated the effects of alkaloids 1 and 2 on PbMLS using pyruvic acid as a positive control [18-19]. Alkaloid 1 exhibited no inhibitory activity against $P b M L S$, but alkaloid 2 inhibited PbMLS with an $\mathrm{IC}_{50}$ of $50 \mu \mathrm{M}$ ( $\odot$ Fig. 2), comparable to that of the positive control, pyruvic acid.

A 3D homology model of PbMLS was built based on the 3D structures of both Escherichia coli and Bacillus anthracis malate synthases A, each of them being 54\% identical to PbMLS (PDB ID: 3CUX; resolution: $1.7 \AA$ ). The Ramachandran plot of the homology model was used to assess the $\Phi$ and $\psi$ distributions. Ninetysix percent of the residues were in the favored region, and $2.9 \%$ were in allowed regions. The quality factor of this structure was estimated to be 72.710 by ERRAT.

PbMLS was subjected to a 200 ns simulation with the program Gromacs to achieve a stable RMSD for the non-hydrogen atoms with respect to the structure homology models.

- Fig. 3 shows that the conformation of PbMLS remained stable at around RMSD $=0.5 \mathrm{~nm}$ after approximately $80 \mathrm{~ns}$ of simulation.

The cluster analysis of the conformations with a cutoff of $0.3 \AA$ allowed the identification of 7 conformations that are capable of the flexibility of PbMLS throughout its trajectory. However, even in an area of transient stability after approximately $80 \mathrm{~ns}$, only one of these conformations was able to effectively represent the trajectory (Fig. 18S, Supporting Information). This conformation (cluster 1) was then used for the molecular docking analysis. This

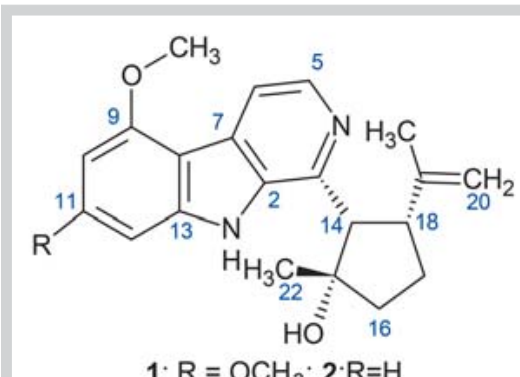

Fig. 1 Structures of alkaloids $\mathbf{1}$ and $\mathbf{2}$ isolated from Galianthe ramosa. (Color figure available online only.)

1: $\mathrm{R}=\mathrm{OCH}_{3} ; 2: \mathrm{R}=\mathrm{H}$
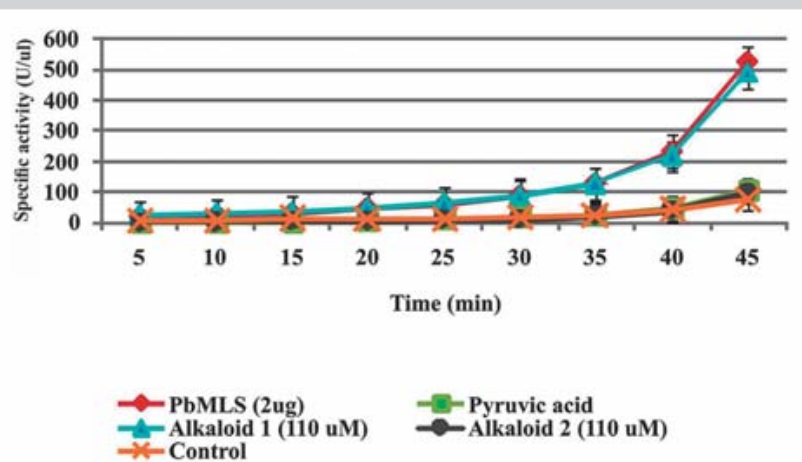

- Pyruvic acid Alkaloid 2 (110 uM)

Fig. $\mathbf{2}$ Influence of alkaloids $\mathbf{1}$ and $\mathbf{2}$ on the activity of malate synthase from Paracoccidioides spp. The relative activity of PbMLS is shown as a function of the concentrations (in $\mu \mathrm{M}$ ) of pyruvic acid (positive control) and indole alkaloids $\mathbf{1}$ and $\mathbf{2}$. Reactions performed with (indicated in red) and without (negative control indicated in yellow) PbMLS served as references. (Color figure available online only.)

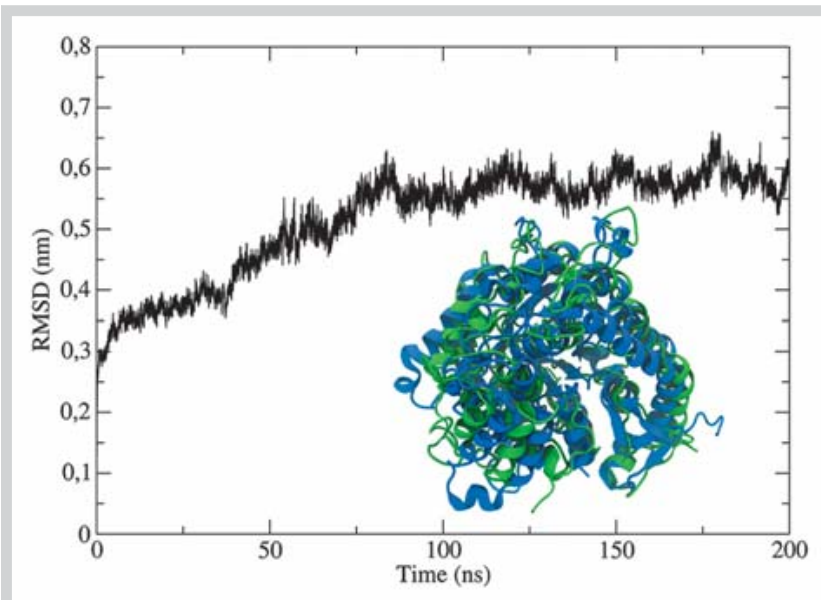

Fig. 3 Dynamic profile for the root-mean-square deviation obtained for the molecular dynamics simulations of isocitrate lyase from Paracoccidioides spp. over 200 ns. The homology model (blue) and the MD structure (green) of $P b M L S$ are superimposed in the inset. (Color figure available online only.)

structure exhibited a higher RMSD with respect to the homology model, with an increase of approximately $5.63 \AA$.

Molecular docking of alkaloids 1 and 2 to PbMSL was performed using AutoDock Vina. Only the best model structures (lowest score) provided by AutoDock Vina were selected. 0 Fig. 4 shows 


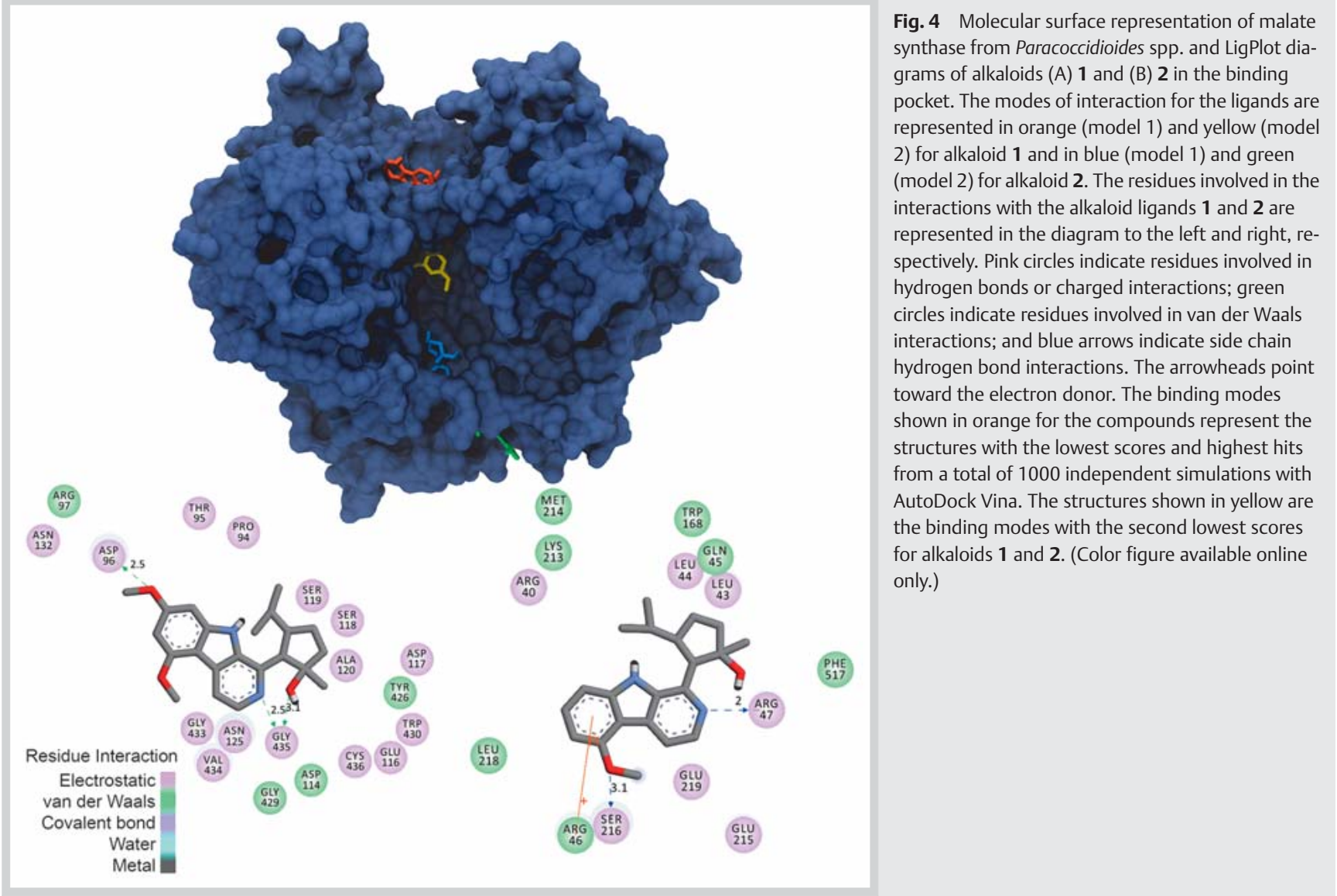

the manner in which each compound is accommodated in the binding pocket and the PbMLS residues that interact most strongly with the ligand.

Notably, as shown in the figure inset, the alkaloids are not bound in the same region of the binding pocket. Strong electrostatic interactions exist between the functional groups present in alkaloid 1 and ASP96 and GLY435 of PbMLS. In the case of ASP96, a hydrogen bond is present in alkaloid 1 between the methoxy group of the indole and the carbon atoms of the indole core, and in alkaloid 2, this interaction occurs with the side chain of SER216. Conversely, stronger electrostatic interactions occur between the $\mathrm{NH}$ of the indole core of alkaloid $\mathbf{2}$ and the side chain of ARG47. The residue ARG46 is critical for the stability of alkaloid 2 through $\pi$-interactions. The heterocycle of $\mathbf{2}$ exists in a more constrained conformation in the cavity, which favors the $\pi$-interactions.

The energies obtained by AutoDock Vina for $\mathbf{1}(-8.0)$ and $\mathbf{2}(-8.8)$ are very close, with a difference of only 0.8 . These data indicate that alkaloid $\mathbf{2}$ tends to be somewhat more stable than 1 (the lower the score, the greater the stability). This small energy difference is certainly not sufficient to explain the differences in the experimental activities of these compounds. However, given the enzyme specificity and their ability to fit into the binding pocket, alkaloid 2 clearly exhibits a greater propensity for binding. LigPlot diagrams of the protein/ligand binding modes ( Fig. 4) suggest that 2 participates in a higher number of nonpolar interactions than 1. As shown in 0 Fig. 4, the pocket of PbMLS contains several cavities, and a perceptible difference exists between the regions of stability for ligands $\mathbf{1}$ and $\mathbf{2}$. Alkaloid $\mathbf{2}$ participates in a larger number of nonpolar contacts, and we be- lieve that this difference is crucial for providing additional stability to compound $\mathbf{2}$. These contacts result in a large increase in the entropy of the medium when the nonpolar groups of $\mathbf{2}$ are in the cavity of PbMLS (greater complementarity). This conclusion is supported by the fact that alkaloid $\mathbf{2}$ has a lower ASA than alkaloid 1. The ASA of alkaloid 2 is almost $100 \AA^{2}$ less than that of alkaloid 1. The nonpolar groups of alkaloid 2 are better protected in the PbMLS cavity ( $\odot$ Fig. 4). Our hypothesis is that the lower hydrophilicity of $\mathbf{2}$ provides sufficient specificity to ensure greater accessibility to the binding pocket, resulting in a lower binding free energy (not estimated here). This difference is certainly very close to the threshold at which $\mathbf{2}$ would lose its stability in the cavity, but it is still sufficient to maintain $\mathbf{2}$ in the cavity.

This difference was also clear when we analyzed the histogram for each compound (not shown here). Nearly 100\% (985/1000) of the simulations for alkaloid 2 demonstrated -8.8 scores for mode 1 , whereas for alkaloid $\mathbf{1}$, these states were not as well-defined as those for alkaloid 2 .

In conclusion, two novel alkaloids $\mathbf{1}$ and $\mathbf{2}$ were isolated from $\mathbf{G}$. ramosa, and alkaloid 2 exhibited activity against Paracoccidioides spp. and the enzyme PbMLS. However, the inhibitory activity of alkaloid $\mathbf{2}$ on enzyme PbMLS does not fully explain its activity against Paracoccidioides spp. so that there are possible additional targets involved. Alkaloid $\mathbf{2}$ is the first example of a MLS inhibitor in the literature. Additionally, the results of molecular docking analyses corroborated the experimental findings. 


\section{Material and Methods}

$\nabla$

\section{General experimental procedures}

IR spectra were obtained with a Perkin Elmer Spectrum 400 FT-IR. ${ }^{1} \mathrm{H},{ }^{13} \mathrm{C}$, and 2D spectra were recorded on a Bruker Avance II 500. HRMS spectra were recorded with a Waters Xevo Q-Tof spectrometer.

\section{Plant material}

Fresh material from G. ramosa (stems, leaves, flowers, and roots) was collected on November 19, 2006 from an area with Cerrado vegetation with rocky outcrops at Cocalzinho, Parque Estadual dos Pireneus $\left(15^{\circ} 48^{\prime} 23^{\prime \prime} \mathrm{S}, 48^{\circ} 49^{\prime} 21^{\prime \prime} \mathrm{W}\right.$; at $1100-1200 \mathrm{~m}$ altitude), Goiás, Brasil.

A voucher specimen was identified by Piero Delprete and deposited at the Herbarium of the Federal University of Goias, Goiânia, Brazil with the collection No. Delprete et al. 9955.

\section{Plant extract and isolation}

The plant material was dried at room temperature, and the dry material was powdered and extracted with $95 \%$ ethanol ((leaves - $87 \mathrm{~g}, 4 \times 0.5 \mathrm{~L})$, stems $(102 \mathrm{~g}, 4 \times 0.5 \mathrm{~L})$, flowers $(22 \mathrm{~g}, 4 \times 0.1 \mathrm{~L})$, and roots $(103 \mathrm{~g}, 4 \times 0.5 \mathrm{~L}))$. The ethanol was removed under reduced pressure distillation using a rotary evaporator to afford the crude EEL (24.5 g), EEF (9.2 g), EES (11.9 g), and EER (12.6 g). The EEL extract was successively partitioned $(3 \times 0.2 \mathrm{~L})$ with $\mathrm{HL}$ $(0.9 \mathrm{~g}), \mathrm{CL}(1.5 \mathrm{~g}), \mathrm{AL}(2.3 \mathrm{~g})$, and ML (5.0 g). This process was repeated with the EES and EER extracts.

The CL fraction $(0.5 \mathrm{~g})$ was fractionated using a chromatographic open column $(2 \times 21 \mathrm{~cm})$ packed with silica gel 60 (Machery-Nagel MN, 70 to 230 mesh, $30 \mathrm{~g}$ ) eluting with a gradient of hexane/ AcOEt $(1: 1)$, AcOEt/MeOH $(9: 1)$, and $\mathrm{MeOH}$. The total volume of each eluent was $300 \mathrm{~mL}$. Thirty fractions were obtained, and these were grouped into 7 subfractions based on TLC analysis: CLF1 (0.02 g), CLF2 (0.03 g), CLF3 (0.01 g), CLF4 (0.04 g), CLF5 $(0.01 \mathrm{~g})$, CLF 6 (0.16 g), and CLF7 (0.30 g). The subfraction CLF6 $(0.16 \mathrm{~g})$ was then fractionated using a chromatographic column $(1 \times 11 \mathrm{~cm})$ packed with silica gel $60(\mathrm{MN}-230$ to 400 mesh) eluting with $\mathrm{CHCl}_{3} / \mathrm{MeOH}(9: 1), \mathrm{CHCl}_{3} / \mathrm{MeOH}(1: 1)$, and $\mathrm{MeOH}$ (100 mL each).

This chromatographic purification yielded 73 fractions, which were grouped into 10 subfractions CLF 6.1 (0.001 g); CLF 6.2 (0.001 g); CLF 6.3 (0.003 g); CLF 6.4 (0.012 g); CLF 6.5 (0.010 g); CLF 6.6 (0.001 g); CLF 6.7 (0.002 g); CLF 6.8 (0.001 g); CLF 6.9 $(0.001 \mathrm{~g})$; and CLF 6.10 (0.125 g). From these subfractions, $12 \mathrm{mg}$ of alkaloid 1 was obtained from CLF 6.4, and $2 \mathrm{mg}$ of alkaloid 2 was isolated from CLF 6.7 (0.001 g) after TLC analysis.

The AL fraction $(2.0 \mathrm{~g})$ was fractionated using a chromatographic column previously packed with silica gel 60 (230 to 400 mesh, $\mathrm{MN}, 2 \times 21 \mathrm{~cm}, 30 \mathrm{~g}$ ) eluting with a gradient of $\mathrm{CHCl}_{3} / \mathrm{MeOH}$. This chromatographic purification yielded 76 fractions, which were grouped into 14 subfractions: ALF1 (0.02 g), ALF2 (0.09 g), ALF3 (0.03 g), ALF4 (0.03 g), ALF5 (0.02 g), ALF6 (0.02 g), ALF7 (0.16 g), ALF8 (0.03 g), ALF9 (0.17 g), ALF10 (0.03 g), ALF11 (0.19 g), ALF12 (0.22 g), ALF13 (0.06 g), and ALF14 (0.57 g).

The subfraction ALF7 (0.16) was then fractionated by silica chromatography (MN, 230 to 400 mesh, $1 \times 12 \mathrm{~cm}, 5 \mathrm{~g}$ ) eluting with $\mathrm{CHCl}_{3} / \mathrm{MeOH}(95 / 5,93 / 7,90 / 10$, and then 100/0). From the subfraction eluted with 95:5 $\mathrm{CHCl}_{3} / \mathrm{MeOH}$, the subfraction ALF7.1 yielded oleanolic acid (20 mg) and the subfraction ALF7.2 ursolic acid (25 mg). From the subfraction eluted with $\mathrm{CHCl}_{3} / \mathrm{MeOH} 90 /$ 10 ALF7.4, we isolated $6 \mathrm{mg}$ of epicatechin.

\section{Minimum inhibitory concentration}

The yeast assay was performed using the microdilution method, as described in the M27-S3 reference method of the CLSI [20], with modifications previously described by de Paula e Silva et al. [21], to determine MIC. Alkaloids 1 and $\mathbf{2}$ from G. ramosa were prepared as described above and diluted according to the CLSI M27-A3 method. The inocula were prepared in RPMI-1640 (GIB$\mathrm{CO}^{\mathrm{TM}}$ ) with L-glutamine and without sodium bicarbonate, supplemented with $2 \%$ glucose and buffered to $\mathrm{pH} 7.0$ using 0.165 M MOPS (Sigma-Aldrich). The isolated Paracoccidioides Pb01 (ATCC-MYA-826) yeast cell suspension was adjusted to a final concentration of $0.5 \times 10^{3}$ to $2.5 \times 10^{3}$ cells/mL in RPMI- 1640 . In 96 -well plates, serial dilutions ( $250 \mathrm{mg} / \mathrm{L}$ to $0.48 \mathrm{mg} / \mathrm{L}$ ) of the analyzed compounds were added to wells containing yeast. The plates were incubated at $35^{\circ} \mathrm{C}$ and $150 \mathrm{rpm}$ for $48 \mathrm{~h}$. After this period, alamarBlue ${ }^{\circledR}$ (BioSource) was used according to the manufacturer's instructions, and the plates were incubated for an additional $24 \mathrm{~h}$, thus requiring $72 \mathrm{~h}$ for the MIC final reading. The lowest concentration of antifungal agent that substantially inhibited the growth of the organism was visually determined and was considered the point at which no change was observed in the original blue color of the reagent.

\section{Malate synthase from Paracoccidioides spp.} activity assays

The activity assays, as well as the inhibition assays using pyruvic acid (Sigma-Aldrich; 99.9\%) and indole alkaloids, were performed as previously described by Roucourt et al. [22]. Pyruvic acid was used as a positive control for PbMLS inhibition. Samples without added PbMLS served as the negative controls. Briefly, an endpoint assay that measured the amount of CoA was used. The number of free thiol groups on CoA was determined using DTNB (Sigma-Aldrich) [23]. The absorption at $415 \mathrm{~nm}$ was measured using a microplate reader (model 680, Bio-Rad Laboratories). DTNB was added to a final concentration of $2 \mathrm{mM}$. The addition of DTNB to the mixture halts the reaction, most likely due to reaction of the DTNB with the free thiol groups of cysteine residues [24]. The standard reaction mixture contained $2 \mu \mathrm{g}$ of PbMLS, $100 \mathrm{mM}$ Tris- $\mathrm{HCl}, 5 \mathrm{mM} \mathrm{MgCl}$, 2 mM glyoxylate (Sigma-Aldrich), and $1 \mathrm{mM}$ acetyl CoA (AppliChem $\mathrm{GmbH}$ ). Unless stated otherwise, the reactions were incubated for $45 \mathrm{~min}$ at $\mathrm{pH} 7.5$. All experiments were conducted in triplicate. Student t-tests were used for statistical comparisons, and the observed differences were statistically significant at $\mathrm{p} \leq 0.05$. The error bars correspond to one standard deviation.

\section{Receptor preparation}

The 3D structure of PbMLS was generated based on the 3D structure of E. coli and B. anthracis malate synthase A (PDB id: 3CUZ) using the Modeller algorithm in the ModWeb server [25]. The quality of the predicted structure was assessed using the NIH-MBI laboratory servers (http://nihserver.mbi.ucla.edu) with ERRAT [26]. The Ramachandran plot of PbMLS was prepared on the RAMPAGE web server [27], and Verify 3D was used to evaluate the environments of the amino acids [28].

MD simulations for this structure were performed with GROMACS [29-31] to reproduce the structural stability of this receptor in its native environment [32]. The particle mesh Ewald method [33] was used with periodic boundary conditions in all directions. The entire system was composed of 5406 atoms of PbMLS, $3 \mathrm{Cl}^{-}$ions, and 22500 solvent atoms. To release conflicting contacts, the simulation was then subjected to minimization using 
the steepest descent energy and was considered complete only when the tolerance of $1000 \mathrm{~kJ} / \mathrm{mol}$ was no longer exceeded. After minimization, the system was subjected to a 100 ps simulation in the NVT and NPT ensembles. For both ensembles, the temperature was set to $300 \mathrm{~K}$, and the position of the protein was restricted. In the NVT ensemble, temperature coupling was performed with the V-rescale Berendsen thermostat (thermostat relaxation constant $=0.1 \mathrm{ps}$ ), and the velocities were determined from the Maxwell distribution. In the NPT ensemble, pressure coupling was performed with the Parrinello-Rahman barostat under the following conditions: pressure, $1 \mathrm{~atm}$; time-step, $2 \mathrm{fs}$; and isothermal compressibility of water, $4.5 \times 10^{-5} \cdot \mathrm{bar}^{-1}$. Only after these steps was the system subjected to MD simulations. The simulation was performed for $200 \mathrm{~ns}$ at a constant temperature of $300 \mathrm{~K}$ and a pressure of $1 \mathrm{~atm}$ with a time-step of $2 \mathrm{fs}$ without restricting the protein conformation. Data concerning the trajectory of these times were collected every 5 ps. Equilibration of the trajectory was assessed by monitoring the equilibration of quantities such as RMSD of non-hydrogen atoms with respect to the initial structure.

The program g_cluster (GROMACS tool) was used to determine the conformations that best represent the structures of the entire trajectory obtained during the simulation. The algorithm gromos, as described by Daura [34], was selected for this purpose. A cutoff of $0.3 \mathrm{~nm}$ for the clusters was used, given the profile of RMSD (evolution of RMSD). The clusters were determined using the non-hydrogen atom RMSD values. To prepare the structures for docking, all of the water molecules were removed from the selected structures.

\section{Ligand preparations}

The 3D structures of $\mathbf{1}$ and $\mathbf{2}$ were generated using the GlycoBioChem PRODRG2 Server [30]. Following conversion of the structures into PDB format, charges and non-polar hydrogen atoms were added using the prepare_receptor4.py script from MGLTools [35], and pdbqt files (format for AutoDock) containing the individual compounds and the receptor were created. The conformations in those files were used as the initial conformations in the molecular docking simulations.

\section{Molecular docking}

The conformations of the compounds on the surface of PbMLS were limited to a region surrounding the binding pocket of the protein, which was defined using the DogSiteScorer - active site prediction and analysis server $[36,37]$. The structure of PbMLS was fixed (rigid) during all docking tests. All stages of the simulations were performed with a flexible ligand structure for the selected PbMLS structure.

AutoDock Vina $[38,39]$ was used for the molecular docking simulations with the PbMLS model and the compounds. The simulations were performed with no preconceived bias toward particular interactions, and the best model structure of the complex was determined according to the optimal simulated stability and accessibility (highest hits). This selection was based on analysis of the histogram of the energies obtained for a total of 1000 independent simulations of each compound. The two most frequent states, with the lower energies in the histogram, were selected as conformational modes.

The scores for the conformations generated by AutoDock Vina (global energy) consider the weak attractive and repulsive van der Waals forces (hydrophobic interactions), hydrogen bonds, and torsional penalties [40].

\section{Theoretical calculations}

The protocol used for these calculations is commonly found in the literature $[41,42]$. The geometries of the cis and trans isomer structures were first optimized using the MP2 method [43] and the cc-pVDZ $[44,45]$ basis sets and included the solvent effect (chloroform) from the polarizable continuum model [46]. After this process, these optimized structures were used to perform the spin-spin coupling constant $(J)$ calculations for the B3LYP functional and cc-pVTZ $[44,45]$ basis sets, which also included solvent effects. All of the calculations were performed using the Gaussian 09 package [47].

\section{Supporting information}

Supporting information shows experimental data for epicatechine and ursolic acid as well as spectra ( ${ }^{1} \mathrm{NMR}, \mathrm{COSY}, \mathrm{HSQC}$, HMBC, NOESY, HRMS) and HMBC and COSY correlation tables for alkaloids $\mathbf{1}$ and $\mathbf{2}$. Two additional figures showing cluster analyses and grid set within the pockets of PbMLS are also available as Supporting Information.

\section{Acknowledgments}

$\nabla$

This work, performed at the Universidade Federal de Goiás, was supported by MCTI/CNPq (Ministério da Ciência e Tecnologia/ Conselho Nacional de Desenvolvimento Científico e Tecnológico), FNDCT (Fundo Nacional de Desenvolvimento Científico e Tecnológico), FAPEG (Fundação de Amparo à Pesquisa do Estado de Goiás), CAPES (Coordenação de Aperfeiçoamento de Pessoal de Nível Superior), FINEP (Financiadora de Estudos e Projetos), and INCT_IF (Instituto Nacional de Ciência e Tecnologia para Inovação Farmacêutica). We also thank Professor Freddy Fernandes Guimarães (Universidade Federal de Goiás) for the theoretical calculations. Additionally, CSF was supported by fellowships from CAPES, and BRSN; GOQ and PGD were supported by CNPq.

\section{Conflict of Interest}

$\nabla$

The authors declare that there are no conflicts of interest.

\section{Affiliations}

${ }^{1}$ Instituto de Química - Universidade Federal de Goiás, Goiânia, GO, Brazil

2 Depto. Química, Universidade Estadual de Maringá, Maringá, PR, Brazil

${ }^{3}$ Herbier de Guyane, IRD, UMR AMAP, Cayenne, French Guiana, France

${ }^{4}$ Núcleo Colaborativo de BioSistemas, Campus Jataí, Universidade Federal de Goiás, Goiânia, GO, Brazil

${ }^{5}$ Instituto de Ciências Biológicas - Universidade Federal de Goiás, Goiânia, GO, Brazil

\section{References}

1 Restrepo A, Mc Eween JG, Castaneda E. The habitat of Paracoccidioides brasiliensis: how far from solving the riddle? Med Mycol 2001; 39: 233-241

2 Bernard G, Kavakama J, Mendes-Giannini MJM, Kono A, Duarte AJ, Shikanai-Yasuda MA. Contribution to the natural history of paracocidioidomycosis: identification of primary pulmonary infection in the severe acute form of the disease - a case report. Clinical Infection Disease 2005; 40: $1-4$

3 Shikanai-Yasuda MA, Queiroz-Telles F, Mendes RP, Colombo AL, Moretti $M L$. Consenso em Paracoccidioidomycosis. Rev Soc Bras Med Trop 2006; 39: 297-310

4 Nunura RJ, Salazar MD, Vásquez LT, Endo GS, Rodríguez FA, Zerpa LR. Paracoccidioidomicosis and multidrug-resistant tuberculosis (TBC-MDR) in patient coinfected with HIV and hepatitis C. Rev Chil Infectol 2010; 27: $551-555$ 
5 Bellissimo-Rodrigues F, Vitali LH, Martinez $R$. Serological diagnosis of paracoccidioidomycosis in HIV-coinfected patients. Mem Inst Oswaldo Cruz 2010; 105: 904-907

6 McKinney JD, Höner zu Bentrup K, Muñoz-Elías EJ, Miczak A, Chen B, Chan WT, Swenson D, Sacchettini JC, Jacobs jr. WR, Russell DG. Persistence of Mycobacterium tuberculosis in macrophages and mice requires the glyoxylate shunt enzyme isocitrate lyase. Nature 2000; 406: 735-738

7 Lorenz MC, Fink GR. Life and death in a macrophage: role of the glyoxylate cycle in virulence. Eukaryotic Cell 2002; 1: 657-662

8 Lorenz MC, Bender JA, Fink GR. Transcriptional response of Candida albicans upon internalization by macrophages. Eukaryotic Cell 2004; 3: 1076-1087

9 Rude TH, Toffaletti DL, Cox GM, Perfect JR. Relationship of the glyoxylate pathway to the pathogenesis of Cryptococcus neoformans. Infect Immun 2002; 70: 5684-5694

10 Thines ER, Webwer RW, Talbot NJ. MAP kinase and protein kinase A-dependent mobilization of triacylglycerol and glycogen during appreorium turgor generation by Magnoporth grisea. Plant Cell 2000; 12: 1703-1708

11 Bastos KP, Bailão AM, Borges CL, Faria FP, Felipe MS, Silva MG, Martins WS, Fiuza RB, Pereira M, Soares CMA. The transcriptome analysis of early morphogenesis in Paracoccidioides brasiliensis mycelium reveals novel and induced genes potentially associated to the dimorphic process. BMC Microbiology 2007; 7: 29

12 Costa M, Borges CL, Bailão AM, Meirelles GV, Mendonça YA, Dantas SF, de Faria FP, Felipe MS, Molinari-Madlum EEWI, Mendes-Giannini MJ, Fiuza $R B$, Martins WS, Pereira M, Soares CMA. Transcriptome profiling of Paracoccidioides brasiliensis yeast-phase cells recovered from infected mice brings new insights into fungal response upon host interaction. Microbiology 2007; 153: 4194-4207

13 Derengowski LS, Tavares AH, Silva S, Procópio LS, Felipe MS, Silva-Pereira I. Upregulation of glyoxylate cycle genes upon Paracoccidioides brasiliensis internalization by murine macrophages and in vitro nutritional stress condition. Med Mycol 2008; 46: 125-134

14 Goldman GH, dos Reis Marques E, Duarte Ribeiro DC, de Souza Bernardes LA, Quiapin AC, Vitorelli PM, Savoldi M, Semighini CP, de Oliveira $R C$, Nunes LR, Travassos LR, Puccia R, Batista WL, Ferreira LE, Moreira JC, Bogossian AP, Tekaia F, Nobrega MP, Nobrega FG, Goldman MH. EST analysis of the human pathogen Paracoccidioides brasiliensis yeast phase: identification of putative homologues of Candida albicans virulence/pathogenicity genes. Eukaryot Cell 2003; 2: 34-48

15 Figueiredo PO, Garcez FR, Matos MFC, Perdomo RT, Queiroz LMM, Pott A, Garcez AJS, Garcez WS. A new cytotoxic b-carboline alkaloid from Galianthe thalictroides. Planta Med 2011; 77: 1852-1854

$16 \mathrm{El-Razek}$ AMH. NMR assignments of four catechi epimers. Asian J Chem 2007; 19: 4867-4872

17 Kim D, Han K, Chung I. Triterpenoids from the flower of Campis grandiflora K. Schum. as human acyl-CoA: cholesterol acyltransferase inhibitors. Arch Pharm Res 2005; 28: 550-556

18 Anstrom DM, Kallio K, Remington SJ. Structure of the Escherichia coli malate synthase $G$ pyruvate: acetylcoenzyme $A$ abortive ternary complex at 1.95 Å resolution. Protein Sci 2003; 12: 1822-1832

19 Munir E, Takefumi H, Mikio S. Purification and characterization of malate synthase from the glucose-grown wood-rotting basidiomycete $F$ mitopsis palustris. Biosci Biotechmol Biochem 2002; 66: 576-581

20 Clinical Laboratory Standard Institute. Reference method for broth dilution antifungal susceptibility testing of filamentous fungi (M38-A2), 2nd edition. Wayne: Clinical Laboratory Standard Institute (CLSI); 2008

21 de Paula e Silva AC, Oliveira HC, Silva JF, Sangalli-Leite F, Scorzoni L, Fusco-Almeida AM, Mendes-Giannini MJ. Microplate alamarBlue assay for Paracoccidioides susceptibility testing. J Clin Microbiol 2013; 51: $1250-1252$

22 Roucourt B, Minnebo N, Augustijns P, Hertveldt K, Volckaert G, Lavigne R. Biochemical characterization of malate synthase $G$ of $P$. aeruginosa. BMC Biochemistry 2009; 10: 1471-2091

23 Ornston LN, Ornston MK. Regulation of glyoxylate metabolism in Escherichia coli K-12. J Bacteriol 1969; 98: 1098-1108

24 Beeckmans S, Khan AS, Kanarek L, Van Driessche E. Ligand binding on to maize (Zea mays) malate synthase: a structural study. Biochem J 1994; 303: 413-421

25 Eswar N, Johr B, Mirkovic N, Fiser A, Ilyn VA, Pierper U, Stuart AC, Martin Renom MA, Madhusudan MS, Yerkovich B. Tools for comparative protein structure modeling and analysis. Nucleic Acids Res 2003; 31: 33753380
26 Colovos C, Yeates TO. Verification of protein structures: Patterns of nonbonded atomic interactions. Protein Science 1993; 2: 1511-1519

27 Lovell SC, Davis IW, Arendall WB, De Bakker PIW, Word JM, Prisant MG, Richardson JS, Richardson DC. Structure validation by $C \alpha$ geometry: $\Phi$, $\Psi$ and $\mathrm{C} \beta$ deviation. Proteins: Struct, Funct, Bioinf 2003; 50: 437-450

28 Luthy R, Bowie JU, Eisenberg D. Assessment of protein models with three-dimensional profiles. Nature 1992; 356: 83-85

29 Van Gusnsteren WF, Billeter SR, Eising AA, Hunenberger PJ, Kroger P, Mark AE, Scott WRP, Tironi IG. Biomolecular simulation: The GROMOS96 manual and user guide. Zurich, Groningen: Biomos b.v.; 1996

30 Berendsen HJC, Van der Spoel D, Van Drunen R. Gromacs: A messagepassing parallel molecular dynamics implementation. Comput Phys Commun 1995; 91: 43-56

31 Lindahl E, Hess B, Van der Spoel D. GROMACS 3.0: a package for molecular simulation and trajectory analysis. J Mol Model 2001; 7: 306-317

32 Kim ND, Chun H, Park SJ, Yang JW, Kim JW, Ahn SK. Discovery of novel HCV polymerase inhibitors using pharmacophore-based virtual screening. Bioorg Med Chem Lett 2011; 21: 3329-3334

33 Darden T, York D, Pedersen L. Particle mesh Ewald: an N.log (N) method for Ewald sums in large systems. J Chem Phys 1993; 98: 10089-10092

34 Daura X, Gademann K, Jaun B, Seebach D, Van Gusteren WF, Mark EA. Peptide folding: when simulation meets experiment. Angew Chem Int 1999; 38: 236-240

35 Schüttelkopf AW, Van Aalten DMF. PRODRG: a tool for high-throughput crystallography of protein-ligand complexes. Acta Crystal Sec D Biol Crystall 2004; 60: 1355-1363

36 Morris GM, Huey R, Lindstrom W, Sanner MF, Belew RK, Goodsell DS, Olson AJ. AutoDock4 and AutoDockTools4: Automated docking with selective receptor flexibility. J Comp Chem 2009; 30: 2785-2791

37 Volkamer A, Kuhn D, Grombacher T, Rippmann F, Rarey M. Combining global and local measures for structure-based druggability predictions. J Chem Info Model 2012; 52: 360-372

38 Volkamer A, Griewel A, Grombacher T, Rarey M. Analyzing the topology of active sites: on the prediction of pockets and subpockets. J Chem Info Model 2010; 50: 2041-2052

39 Trott O, Olson AJ. AutoDock Vina: improving the speed and accuracy of docking with a new scoring function, efficient optimization, and multithreading. J Comp Chem 2011; 31: 455-461

40 Chang MW, Ayeni C, Breuer S, Torbett BE. Virtual screening for HIV protease inhibitors: a comparison of AutoDock 4 and Vina. PloS one 2010; 5: e11955

41 Queiroz jr. LHK, Lacerda jr. V, dos Santos RB, Greco SJ, Neto AC, Castro EVR. NMR property calculations and experimental study of the 1,6-epoxycarvone and $\alpha$-epoxypinene: a comparison of models. Magn Reson Chem 2011; 49: 140-146

42 Oliveira KT, Lacerda jr. V, Constantino MG, Donate PM, da Silva GVJ, Brocksom TJ, Frederico D. Analysis of a cycloheptenone derivative: An experimental and theoretical approach. Spectrochim Acta A 2006; 63: 709-713

43 Møller C, Plesset MS. Note on an approximation treatment for manyelectron systems. Phys Rev 1934; 46: 618-622

44 Dunning TH. Gaussian basis sets for use in correlated molecular calculations. I. The atoms boron through neon and hydrogen. J Chem Phys 1989; 90: 1007-1023

45 Woon D, Dunning TH. Gaussian basis sets for use in correlated molecular calculations. IV. Calculation of static electrical response properties. J Chem Phys 1995; 100: 2975-2988

46 Miertus S, Scrocco E, Tomasi J. Electrostatic interaction of a solute with a continuum. A direct utilization of $a b$ initio molecular potentials for the prevision of solvent effects. Chem Phys 1981; 55: 117-129

47 Frisch MJ, Trucks GW, Schlegel HB, Scuseria GE, Robb MA, Cheeseman JR, Scalmani G, Barone V, Mennucci B, Petersson GA, Nakatsuji H, Caricato $M$, Li X, Hratchian HP, Izmaylov AF, Bloino J, Zheng G, Sonnenberg JL, Hada M, Ehara M, Toyota K, Fukuda R, Hasegawa J, Ishida M, Nakajima T, Honda Y, Kitao O, Nakai H, Vreven T, Montgomery JA, Peralta JE, Ogliaro F, Bearpark M, Heyd IJ, Brothers E, Kudin KN, Staroverov VN, Kobayashi R, Normand J, Raghavachari K, Rendell A, Burant JC, Iyengar SS, Tomasi J, Cossi M, Rega N, Millam JM, Klene M, Knox JE, Cross JB, Bakken V, Adamo C, Jaramillo J, Gomperts R, Stratmann RE, Yazyev O, Austin AJ, Cammi R, Pomelli C, Ochterski JW, Martin RL, Morokuma K, Zakrzewski VG, Voth GA, Salvador P, Dannenberg JJ, Dapprich S, Daniels AD, Farkas O, Foresman JB, Ortiz JV, Cioslowski J, Fox DJ. Gaussian 09, Revision A02. Wallingford: Gaussian, Inc.; 2009 